\title{
Azospirillum inoculation of 'Marandu' palisade grass seeds: effects on forage production and nutritional status
}

\section{Inoculação do Azospirillum em sementes de capim Marandu: efeitos na produção de forragem e estado nutricional}

\author{
Reges Heinrichs ${ }^{1}$; Guilherme Constantino Meirelles'; Luiz Felipe de Melo \\ Santos $^{3 *}$; Maikon Vinicius da Silva Lira ${ }^{4}$; Allan de Marcos Lapaz ${ }^{5}$; Marco Antonio \\ Nogueira $^{6}$; Carolina dos Santos Batista Bonini ${ }^{1}$; Cecílio Viega Soares Filho \\ Adônis Moreira ${ }^{6}$
}

Highlights:

Seed inoculation increased root and shoot dry mass.

Nitrogen fertilization altered nutrient concentrations in shoot dry mass.

Nitrogen fertilization increased tiller numbers.

\begin{abstract}
Plant-growth-promoting bacteria can be used for sustainable forage grass production while increasing nutrition and biomass. Most of the soils under pasture in the tropics have a degradation level that impairs the forage yield potential, especially because of mismanagement and lack of fertilization. The objective of this work was to evaluate the seed inoculation effects of Azospirillum brasilense on the shoot and root dry mass production and nutritional status of Urochloa brizantha cv. 'Marandu' under field conditions for two years in a low-fertility soil. The experimental design was a randomized block design with four replications, arranged in a $2 \times 3$ factorial scheme, comprised of two doses of A. brasilense $(0$ and $200 \mathrm{~mL}$ $\left.\mathrm{ha}^{-1}\right)$ in combination with three doses of $\mathrm{N}\left(0,25\right.$ and $\left.50 \mathrm{~kg} \mathrm{ha}^{-1}\right)$. Seed inoculation increased shoot dry mass by $13 \%$ in the first year and by $6 \%$ in the second year, whereas $\mathrm{N}$ application increased dry mass by $27 \%$ and $35 \%$ in the first and second year, respectively. The concentration of nutrients in the shoots did not change due to the inoculation, but $\mathrm{N}$ fertilization affected $\mathrm{P}, \mathrm{Mg}, \mathrm{Fe}, \mathrm{Mn}$, and $\mathrm{Zn}$ in the first year and $\mathrm{N}, \mathrm{P}$ and $\mathrm{Cu}$ in the second year. Root dry mass increased $36 \%$ with fertilization of $25 \mathrm{~kg} \mathrm{~N}^{-1}$ plus inoculation in relation to the other treatments in the first year. In the second year, the inoculation of $A$. brasilense increased by $17 \%$. Therefore, seed inoculation of Urochloa brizantha cv. 'Marandu' with Azospirillum brasilense increased root and shoot dry mass production in some cuts without influencing
\end{abstract}

\footnotetext{
1 Profs. Drs., Faculdade de Ciências Agrárias e Tecnológicas, Universidade Estadual Paulista, UNESP, Campus de Dracena, SP, Brasil. E-mail: reges.heinrichs@unesp.br; carolina.bonini@unesp.br

2 Discente do Curso de Doutorado do Programa de Pós-Graduação em Agronomia: Agricultura, Faculdade de Ciências Agronômicas, UNESP, Campus de Botucatu, SP, Brasil. E-mail: gui_meirelles2312@hotmail.com

3 M.e, Programa de Pós-Graduação em Ciência e Tecnologia Animal, Faculdade de Ciências Agrárias e Tecnológicas, UNESP, Campus de Dracena, SP, Brasil. E-mail: melo.santos195@gmail.com

4 Discente do Curso de Doutorado do Programa de Pós-Graduação em Agronomia, Universidade do Oeste Paulista, UNOESTE, Presidente Prudente, SP, Brasil. E-mail: maikonvinicius@hotmail.com

5 Discente do Curso de Mestrado do Programa de Pós-Graduação em Agronomia, Faculdade de Engenharia da UNESP, Campus de Ilha Solteira, SP, Brasil. E-mail: allanlapaz60@gmail.com

6 Pesquisadores Drs., Empresa Brasileira de Pesquisa Agropecuária, EMBRAPA Soja, Londrina, PR, Brasil. E-mail: marco. nogueira@embrapa.br; adonis.moreira@embrapa.br

7 Prof. Dr., Faculdade de Medicina Veterinária, UNESP, Campus de Araçatuba, SP, Brasil. E-mail: cecilio@fmva.unesp.br

*Author for correspondence
} 
tiller numbers. Nitrogen fertilization altered $\mathrm{N}, \mathrm{Mg}, \mathrm{P}, \mathrm{Fe}, \mathrm{Mn}, \mathrm{Zn}$, and $\mathrm{Cu}$ concentrations in shoot dry mass.

Key words: Diazotrophic bacteria. Nitrogen. Growth promoting. Pasture. Urochloa brizantha.

\section{Resumo}

As bactérias promotoras de crescimento de plantas podem ser usadas para a produção sustentável de gramíneas forrageiras, aumentando a nutrição e a biomassa. A maioria dos solos sob pastagem nos trópicos apresenta um certo nível de degradação que prejudica o potencial de produção de forragem, principalmente por causa de má gestão e falta de fertilização. O objetivo deste trabalho foi avaliar os efeitos da inoculação de sementes de Azospirillum brasilense na produção de massa seca da parte aérea e da raiz e o estado nutricional do Urochloa brizantha cv. Marandu sob condições de campo por dois anos em um solo de baixa fertilidade. O delineamento experimental foi em blocos casualizados com quatro repetições, dispostos em esquema fatorial $2 \times 3$, composto por duas doses de $A$. brasilense $(0$ e $200 \mathrm{~mL}$ $\left.\mathrm{ha}^{-1}\right)$ em combinação com três doses de $\mathrm{N}\left(0,25\right.$ e $\left.50 \mathrm{~kg} \mathrm{ha}^{-1}\right)$. A inoculação das sementes aumentou a massa seca da parte aérea em $13 \%$ no primeiro ano e em $6 \%$ no segundo ano, enquanto a aplicação de $\mathrm{N}$ aumentou $27 \%$ e $35 \%$ no primeiro e segundo ano, respectivamente. A concentração de nutrientes na parte aérea não foi alterada devido à inoculação, porém a adubação nitrogenada afetou $\mathrm{P}, \mathrm{Mg}, \mathrm{Fe}, \mathrm{Mn}$ e $\mathrm{Zn}$ no primeiro ano e $\mathrm{N}, \mathrm{P}$ e $\mathrm{Cu}$ no segundo ano. A massa seca da raiz aumentou $36 \%$ com a adubação de $25 \mathrm{~kg} \mathrm{~N} \mathrm{ha}^{-1}$ combinado com a inoculação em relação aos demais tratamentos, no primeiro ano. No segundo ano, a inoculação de $A$. brasilense aumentou em 17\%. Portanto, a inoculação de sementes de Urochloa brizantha cv. 'Marandu' com o Azospirillum brasilense aumentou a produção de massa seca da raiz e da parte aérea em alguns cortes sem influenciar o número de perfilhos. A adubação nitrogenada alterou as concentrações de $\mathrm{N}, \mathrm{Mg}, \mathrm{P}, \mathrm{Fe}, \mathrm{Mn}, \mathrm{Zn}$ e $\mathrm{Cu}$ da massa seca da parte aérea.

Palavras-chave: Bactérias diazotróficas. Nitrogênio. Promotor de crescimento. Pastagem. Urochloa brizantha.

\section{Introduction}

Forage grass is the most economical and practical way for feeding cattle in the tropical regions, as climatic conditions favor the maximum potential for forage production (Hungria, Nogueira, \& Araujo, 2016; Morais et al., 2014). The genus Urochloa (Brachiaria) is distributed throughout the tropical zones, and has a high potential for forage production, with high rusticity and adaptation to acid, low-fertility soils, and it shows high responsiveness to fertilizer application (Cezário, Ribeiro, Santos, Valadares, \& Pereira, 2015; Medica, Reis, \& Santos, 2017).

Most of the soils under pasture in the tropics have a degradation level that impairs the forage yield potential, especially because of mismanagement and lack of fertilization (Nesper et al., 2015). The area with pastures in Brazil is estimated to be about 180 million ha, with about $70 \%$ under some level of degradation (Dias, 2014). This scenario is aggravated because naturally low-fertility soils are used extensively for pastures. In addition, the natural decline of soil fertility, especially of phosphorus and nitrogen, and increases of acidity and toxic aluminum (Lopes \& Guilherme, 2016) are limiting for forage growth and the capacity to feed animals.

Nutrition with nitrogen is a key feature to maintain or increase the potential yields of forage grasses due to its influence on plant biomass (Chinnadurai, Gopalaswamy, \& Balachandar, 2014; Fagundes et al., 2006), especially leaf size, stem morphology, and the development of tillers (Taiz, Zeiger, Møller, \& Murphy, 2017). However, its high price limits its broad use in extensive pastures. On the other hand, its excessive use may cause contamination of surface- and ground waters with nitrate and increase greenhouse gas emissions (De Salamone et al., 2010). Therefore, the use of plantgrowth-promoting bacteria, especially diazotrophs, 
could increase the effectiveness of $\mathrm{N}$ use by grasses (Piccinin et al., 2013), especially in low-fertility soils (Carvalhais et al., 2013; Hungria, Campo, Souza, \& Pedrosa, 2010; Hungria et al., 2016).

Plant-growth-promoting bacteria increase root growth, favoring the uptake of water and nutrients (El Zemrany et al., 2007; Huang et al., 2017; Shaharoona, Jamro, Zahir, Arshad, \& Memon, 2007). Several mechanisms are usually involved, especially phytohormone production, including auxins, gibberellins, cytokinins, and ethylene, as well as $\mathrm{P}$ solubilization and biological nitrogen fixation, which may result in increased plant growth and tolerance to stresses like drought, salinity, and metal toxicity (Bashan \& de-Bashan, 2005; Delaporte-Quintana et al., 2017).

Azospirillum is one of the most well-studied plant-growth-promoting rhizobacteria that has been shown to increase yields of grasses like corn (Zea mays), wheat (Triticum aestivum) (Hungria et al., 2010; Kazi, Deaker, Wilson, Muhammad, \& Trethowan, 2016), rice (Oryza sativa) (De Salamone et al., 2010), Brachiaria spp. (Hungria et al., 2016), and sugarcane (Saccharum) (Moutia, Saumtally, Spaepen, \& Vanderleyden, 2010), as well as legumes like soybean and common-beans (Hungria, Nogueira, \& Araujo, 2013).
Based on the hypothesis that the presence of Azospirillum brasilense may supply part of the nitrogen demand in Urochloa brizantha cv. 'Marandu', this research was conducted in order to evaluate the seed inoculation effect in Azospirillum brasilense on the shoot and root dry mass production and nutritional status under field conditions in a natural low-fertility soil.

\section{Material and Methods}

\section{Experimental sites}

The experiment was carried out in the experimental area of College of Agricultural and Technological Sciences, São Paulo State University (UNESP), São Paulo State, Brazil (21 ${ }^{\circ} 29^{\prime} \mathrm{S} ; 51^{\circ} 32^{\prime} \mathrm{W} ; 396 \mathrm{~m}$ above sea level), during two years (November 2014 to February 2015 and November 2015 to February 2016), at two different sites. The climate, according to Köppen, is Aw, characterized by hot and humid summers and warm and dry winters, with most of the rainfall distributed between November and March. The average annual temperature and rainfall are, respectively, $24{ }^{\circ} \mathrm{C}$ and $1,300 \mathrm{~mm}$, with an average maximum temperature of $31{ }^{\circ} \mathrm{C}$ and an average minimum of $19^{\circ} \mathrm{C}$. Details on the climatic events during the experiment are in Figure 1.

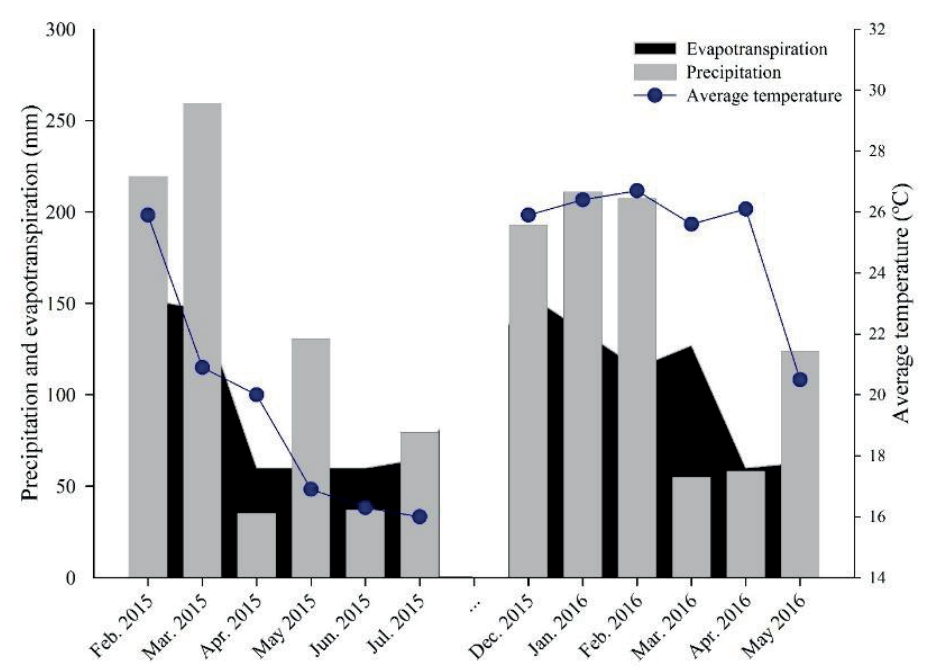

Figure 1. Monthly average temperature $\left({ }^{\circ} \mathrm{C}\right)$, precipitation, and evapotranspiration $(\mathrm{mm})$ during the two crop seasons (2014/2015 and 2015/2016). 
The soil was classified as an Ultisol (Santos et al., 2018) and sampled at a 0-20 cm depth before the experiment installation for analysis of chemical properties and granulometric fractions (Table 1). The need for liming was determined from the base saturation method to reach $60 \%$ of CEC (Quaggio, Van Raij, \& Malavolta, 1985). The limestone was distributed homogeneously on the soil surface and incorporated by plowing at a $20 \mathrm{~cm}$ depth. The native diazotrophic bacteria population in the experimental soil at the $0-10 \mathrm{~cm}$ layer was determined by the most probable number (MPN) method in $\mathrm{N}$-free $\mathrm{NFb}$ semisolid culture medium (Baldani, Reis, Videira, Boddey, \& Baldani, 2014), as described in table 2.

Table 1

Chemical attributes and granulometric fractions at 0-20 $\mathrm{cm}$ of an Ultisol in two cropping seasons at the beginning of the experiment

\begin{tabular}{|c|c|c|c|c|c|c|c|c|c|c|c|}
\hline Season & \multicolumn{2}{|c|}{$\mathrm{pH}$} & $\mathrm{OM}$ & $\mathrm{P}$ & $\mathrm{K}$ & $\mathrm{Ca}$ & $\mathrm{Mg}$ & $\mathrm{H}+\mathrm{Al}$ & $\mathrm{Al}$ & SB & CEC \\
\hline & & & $\mathrm{g} \mathrm{dm}^{-3}$ & $\mathrm{mg} \mathrm{dm}^{-3}$ & & - & - & $\mathrm{mmol}_{\mathrm{c}}$ & $-3-\cdots$ & - & --- \\
\hline $2014 / 15$ & \multicolumn{2}{|c|}{5.0} & 14 & 8 & 2.6 & 9 & 6 & 18 & 0 & 18 & 36 \\
\hline $2015 / 16$ & \multicolumn{2}{|c|}{4.7} & 5 & 4 & 3.0 & 8 & 5 & 20 & 2 & 16 & 36 \\
\hline \multirow[t]{2}{*}{ Season } & $\mathrm{V}$ & $\mathrm{m}$ & $S$ & $\mathrm{~B}$ & $\mathrm{Cu}$ & $\mathrm{Fe}$ & $\mathrm{Mn}$ & $\mathrm{Zn}$ & Clay & Silt & Sand \\
\hline & \multicolumn{2}{|c|}{-----\%---- } & \multicolumn{6}{|c|}{ 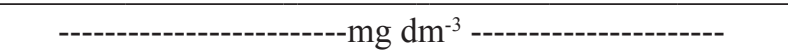 } & \multicolumn{3}{|c|}{------- g kg $^{-1}$------- } \\
\hline $2014 / 15$ & 49 & 0 & 7 & 0.18 & 2.9 & 25 & 19 & 1.2 & 123 & 27 & 850 \\
\hline 2015/16 & 44 & 11 & 4 & 0.19 & 0.8 & 24 & 15 & 1.2 & 120 & 30 & 850 \\
\hline
\end{tabular}

$\mathrm{pH}$ in $0.01 \mathrm{~mol} \mathrm{~L}^{-1} \mathrm{CaCl}_{2}$; $\mathrm{P}, \mathrm{Ca}, \mathrm{Mg}$ and $\mathrm{K}$ (ion-exchanging resin); $\mathrm{S}$ (calcium phosphate); $\mathrm{B}$ (hot water); $\mathrm{SB}$ (sum of bases $=\mathrm{K}+$ $\mathrm{Ca}+\mathrm{Mg}$ ); $\mathrm{Cu}, \mathrm{Fe}, \mathrm{Mn}$, and $\mathrm{Zn}$ (DTPA at pH 7.3); OM: organic matter; CEC: cation exchangeable capacity; V: \% of CEC occupied by bases; $\mathrm{m}$ : \% of CEC occupied by Al.

Table 2

Population of native diazotrophic bacteria in the soil at the beginning of the experiment

\begin{tabular}{ccc}
\hline \multirow{2}{*}{ Sample } & \multicolumn{2}{c}{ MPN g-1 $^{-1}$} \\
\cline { 2 - 3 } & $2014 / 2015$ & $2015 / 2016$ \\
\hline 1 & $2.5 \times 10^{6}$ & $9.5 \times 10^{5}$ \\
2 & $9.5 \times 10^{6}$ & $4.5 \times 10^{6}$ \\
3 & $9.5 \times 10^{6}$ & $9.5 \times 10^{5}$ \\
\hline
\end{tabular}

Method: Most probable number (MPN) in multiple vials with semi-solid NFb medium.

\section{Experimental design and treatments}

The experiment was installed in 2014/15 and sowing was repeated in the seasons of $2015 / 16$, in plots of $3 \times 4 \mathrm{~m}$. The experiment was arranged in a randomized block design with four replications in a $2 \times 3$ factorial scheme. The treatments were seeds of Urochloa brizantha (syn. Brachiaria brizantha) cv. 'Marandu' that had been inoculated with Azospirillum brasilense or not inoculated. The inoculant was a liquid formulation of a commercial inoculant (Masterfix Gramineas ${ }^{\mathrm{TM}}$, Soller, Cosmópolis, Brazil) containing the strains Ab-V5 and $\mathrm{Ab}-\mathrm{V} 6$ at the concentration of $2 \times 10^{8} \mathrm{CFU}$ $\mathrm{mL}^{-1}$. It is currently registered, recommended, and available in the Brazilian market as a commercial product containing PGPB for wheat, maize, and rice. $12 \mathrm{~kg} \mathrm{ha}^{-1}$ of viable pure seeds were used. The inoculant was diluted in deionized water to assure a uniform distribution on the seeds, at a proportion of $100 \mathrm{~mL}$ of solution (water + inoculant) per $\mathrm{kg}$ 
of seeds. In the controls (non-inoculated), only water was added to assure the same pre-seeding procedure. Seeds were allowed to dry under shade and manually distributed on the plots. These treatments were combined with three $\mathrm{N}$ doses $(0,25$ and $50 \mathrm{~kg} \mathrm{ha}^{-1}$ as $\mathrm{NH}_{4} \mathrm{NO}_{3}$ ), applied at sowing and as topdressing after each cutting.

Phosphate fertilization consisted of $60 \mathrm{~kg} \mathrm{P}_{2} \mathrm{O}_{5}$ $\mathrm{ha}^{-1}$ and $80 \mathrm{~kg} \mathrm{P}_{2} \mathrm{O}_{5} \mathrm{ha}^{-1}$ as triple superphosphate in $2014 / 15$ and in 2015/16 season, respectively. The fertilizer was distributed manually and incorporated at a $0-10 \mathrm{~cm}$ depth. Potassium was suppressed in both seasons because the available $\mathrm{K}$ in soil as considered sufficient to the crop (Table 1).

\section{Samplings and analysis}

In the first year, the experimental cuts were performed on $09 / 01 / 2015,09 / 02 / 2015$, and $07 / 03 / 2015$. In the second year, the cuts were on $18 / 01 / 2016,29 / 02 / 2016$, and 31/03/2016. For yield determination, only the useful area of the plot was considered, the $0.5 \mathrm{~m}$ around it was disregarded. The tiller number was counted the day before the forage was cut, in an area of $0.25 \times 1 \mathrm{~m}$ at the center of each plot. Cuttings were performed three times during the rainy season to determine the plant dry mass when the best treatment reached $28 \mathrm{~cm}$ in height, corresponding to $95 \%$ of light interception (Pedreira, Pedreira, \& Silva, 2007). The samples for shoot dry mass estimation were taken with a sampler device delimiting a $0.5 \times 1 \mathrm{~m}$ area and cutting the plants at $15 \mathrm{~cm}$ height above the soil with the aid of a $60 \mathrm{~cm}$ blade slip on the sampler support to standardize the samplings.

After the third cut, root samples were also collected. A cylindrical sampler $10 \mathrm{~cm}$ in height and with a volume of $151.09 \mathrm{~cm}^{3}$ was used for taking three core soil samples per plot next to the plants, and then it was washed to remove the adhering soil. Shoots and roots were oven-dried at $65{ }^{\circ} \mathrm{C}$ to a constant weight. After weighing, the samples were ground in a Wiley mill and the macro and micronutrient concentrations were analyzed (Malavolta, Vitti, \& Oliveira, 1997).

\section{Statistical analysis}

Data were tested for normality and homogeneity of variance previously to ANOVA, followed by Tukey multiple comparison tests at $P \leq 0.05$ using SAS (Statistical Analysis System, version 8.2) (Pimentel-Gomes \& Garcia, 2002).

\section{Results}

The inoculation with Azospirillum brasilense did not affect the tiller numbers in both seasons. On the other hand, nitrogen fertilization increased the tillering in the first cut, without differing between the 25 and $50 \mathrm{~kg} \mathrm{ha}^{-1}$ of $\mathrm{N}$ treatments (Table 3). There was no interaction between inoculation with Azospirillum and nitrogen fertilization.

Isolated inoculation with Azospirillum or $\mathrm{N}$ fertilization effects were observed for shoot dry mass (Table 4). In the first year, a significant effect of Azospirillum brasilense was observed in the third cutting and in the accumulated cuttings, with increased by $22 \%$ and $13 \%$, respectively, on the noninoculated control. In the second year, there was a significant response to Azospirillum brasilense $(+15 \%)$ only in the first cutting (Table 4$)$.

In the first year, the $50 \mathrm{~kg} \mathrm{ha}^{-1}$ of $\mathrm{N}$ application increased the shoot dry mass in the third cut and in the accumulated cuttings, by $40 \%$ and $27 \%$, respectively, compared with the $\mathrm{N}$ control, whereas $25 \mathrm{~kg} \mathrm{ha}^{-1}$ of $\mathrm{N}$ did not provide significant effect, as also observed for tillering. In the second year, 50 $\mathrm{kg} \mathrm{ha}^{-1}$ of $\mathrm{N}$ significantly increased the shoot dry mass production in the first and third cuttings, and the cumulative cuttings by $78 \%, 18 \%$ and $35 \%$, respectively, over the control (Table 4). The $25 \mathrm{~kg}$ $\mathrm{ha}^{-1}$ of $\mathrm{N}$ dose did not differ from the control in the second and third cuts, but provided significantly higher shoot dry mass in the first cutting and the accumulated cuttings. 
Table 3

Effects of Azospirillum brasilense and nitrogen doses on the number of tillers of Urochloa brizantha cv. 'Marandu' during each of three cuttings and the total of three cuttings, in the seasons 2014/2015 and 2015/2016

\begin{tabular}{|c|c|c|c|c|}
\hline \multirow{2}{*}{ Treatments } & $1^{\text {st }} \mathrm{Cut}\left(\# \mathrm{~m}^{-2}\right)$ & $2^{\text {nd }}$ Cut $\left(\# m^{-2}\right)$ & $3^{\text {rd }}$ Cut $\left(\# m^{-2}\right)$ & Total $\left(\# \mathrm{~m}^{-2}\right)$ \\
\hline & \multicolumn{3}{|c|}{$2014 / 2015$} & \\
\hline No Inoculation & 592 & 786 & 845 & 2223 \\
\hline Inoculation & 547 & 760 & 811 & 2119 \\
\hline MSD (5\%) & 114 & 173 & 190 & 394 \\
\hline \multicolumn{5}{|l|}{ Nitrogen Dose } \\
\hline $0 \mathrm{~kg} \mathrm{ha}^{-1}$ & $464 \mathrm{~b}$ & 673 & 751 & 1913 \\
\hline $25 \mathrm{~kg} \mathrm{ha}^{-1}$ & $625 \mathrm{a}$ & 859 & 956 & 2441 \\
\hline $50 \mathrm{~kg} \mathrm{ha}^{-1}$ & $620 \mathrm{a}$ & 787 & 775 & 2160 \\
\hline $\operatorname{MSD}(5 \%)$ & 152 & 257 & 283 & 587 \\
\hline \multicolumn{5}{|l|}{ F Test } \\
\hline Inoculation (I) & $0.68^{\mathrm{ns}}$ & $0.10^{\mathrm{ns}}$ & $0.14^{\mathrm{ns}}$ & $0.31^{\mathrm{ns}}$ \\
\hline Nitrogen Dose $(\mathrm{N})$ & $3.77^{*}$ & $1.73^{\mathrm{ns}}$ & $2.03^{\mathrm{ns}}$ & $2.64^{\mathrm{ns}}$ \\
\hline $\mathrm{I} \times \mathrm{N}$ & $0.26^{\mathrm{ns}}$ & $0.38^{\mathrm{ns}}$ & $0.21^{\mathrm{ns}}$ & $0.25^{\mathrm{ns}}$ \\
\hline CV (\%) & 23.37 & 26.08 & 26.85 & 21.19 \\
\hline \multicolumn{5}{|c|}{$2015 / 2016$} \\
\hline No Inoculation & 464 & 690 & 881 & 2037 \\
\hline Inoculation & 485 & 670 & 965 & 2121 \\
\hline MSD (5\%) & 50 & 134 & 212 & 315 \\
\hline \multicolumn{5}{|l|}{ Nitrogen Dose } \\
\hline $0 \mathrm{~kg} \mathrm{ha}^{-1}$ & $430 \mathrm{~b}$ & 640 & 880 & 1950 \\
\hline $25 \mathrm{~kg} \mathrm{ha}^{-1}$ & $489 \mathrm{ab}$ & 746 & 948 & 2183 \\
\hline $50 \mathrm{~kg} \mathrm{ha}^{-1}$ & $505 \mathrm{a}$ & 655 & 941 & 2103 \\
\hline MSD (5\%) & 75 & 199 & 315 & 469 \\
\hline \multicolumn{5}{|l|}{ F Test } \\
\hline Inoculation (I) & $0.75^{\mathrm{ns}}$ & $0.10^{\mathrm{ns}}$ & $0.68^{\mathrm{ns}}$ & $0.31^{\mathrm{ns}}$ \\
\hline Nitrogen Dose $(\mathrm{N})$ & $3.64^{*}$ & $1.06^{\mathrm{ns}}$ & $0.19^{\mathrm{ns}}$ & $0.83^{\mathrm{ns}}$ \\
\hline $\mathrm{I} \times \mathrm{N}$ & $2.40^{\mathrm{ns}}$ & $0.46^{\mathrm{ns}}$ & $0.69^{\mathrm{ns}}$ & $0.79^{\mathrm{ns}}$ \\
\hline CV (\%) & 12.42 & 23.01 & 26.73 & 17.69 \\
\hline
\end{tabular}

MSD: minimal significant difference. Means followed by the same letter do not differ statistically from each other by the Tukey's test at $P \leq 0.05$. ", significant at $P \leq 0.05$; ${ }^{\text {ns }}$ not significant.

For nutrient concentration in shoots, $\mathrm{N}$ fertilization affected only some elements (Table 5), whereas the inoculation with Azospirillum did not cause any effect (not shown). The $\mathrm{N}$ doses increased the shoot $\mathrm{N}$ concentration only in the second year, in the first and third cuttings. The $\mathrm{P}$ concentration in both years in the third cut was higher in the treatments without $\mathrm{N}$ application. $\mathrm{Mg}, \mathrm{Fe}, \mathrm{Mn}$ and $\mathrm{Zn}$ in the first cutting of the first year and $\mathrm{Cu}$ in the third cutting of the second year increased with $50 \mathrm{~kg}$ ha ${ }^{-1}$ of $\mathrm{N}$ (Table 5).

The root dry mass (RDM) production in the first year showed an interaction between inoculation and $\mathrm{N}$ doses (Figure 2). The maximum RDM yield 
was obtained with $25 \mathrm{~N} \mathrm{~kg} \mathrm{ha}^{-1}$ in conjunction with inoculation, and was significantly higher by $82 \%, 25 \%$, and $32 \%$ in comparison to $25 \mathrm{~kg} \mathrm{~N} \mathrm{ha}^{-1}$ treatments without inoculation as well as $0 \mathrm{~kg} \mathrm{~N}$ $\mathrm{ha}^{-1}$ and $50 \mathrm{~kg} \mathrm{~N} \mathrm{ha}^{-1}$ treatments plus inoculation. In relation to the treatments that did not receive inoculation, the fertilization with $0 \mathrm{~kg} \mathrm{ha}^{-1}$ and 50 $\mathrm{kg} \mathrm{N} \mathrm{ha}^{-1}$ were statistically superior to $25 \mathrm{~kg} \mathrm{~N}^{-1}$ (Figure 2). In the second year, the RDM production had a significant effect only for inoculation with Azospirillum. The inoculation promoted an increase of $17 \%$ when compared to non-inoculated plants (Figure 3).

Table 4

Effects of Azospirillum brasilense or nitrogen doses on the shoot mass production of Urochloa brizantha cv. 'Marandu' during tree cuttings and total of three cuttings, in the seasons 2014/2015 and 2015/2016

\begin{tabular}{|c|c|c|c|c|}
\hline \multirow{2}{*}{ Treatments } & $1^{\text {st }}$ Cut $\left(\mathrm{kg} \mathrm{ha}^{-1}\right)$ & $2^{\text {nd }}$ Cut $\left(\mathrm{kg} \mathrm{ha}^{-1}\right)$ & $3^{\text {rd }}$ Cut $\left(\mathrm{kg} \mathrm{ha}^{-1}\right)$ & Total $\left(\mathrm{kg} \mathrm{ha}^{-1}\right)$ \\
\hline & \multicolumn{3}{|c|}{$2014 / 2015$} & \\
\hline No Inoculation & 2290 & 2084 & $2396 \mathrm{~b}$ & $6769 \mathrm{~b}$ \\
\hline Inoculation & 2530 & 2177 & 2933 a & 7639 a \\
\hline MSD (5\%) & 394 & 700 & 418 & 853 \\
\hline \multicolumn{5}{|l|}{ Nitrogen Dose } \\
\hline $0 \mathrm{~kg} \mathrm{ha}^{-1}$ & 2314 & 1702 & $2274 \mathrm{~b}$ & $6290 \mathrm{~b}$ \\
\hline $25 \mathrm{~kg} \mathrm{ha}^{-1}$ & 2555 & 2242 & $2528 \mathrm{~b}$ & $7324 \mathrm{ab}$ \\
\hline $50 \mathrm{~kg} \mathrm{ha}^{-1}$ & 2361 & 2448 & $3190 \mathrm{a}$ & 7999 a \\
\hline $\operatorname{MSD}(5 \%)$ & 585 & 1042 & 621 & 1418 \\
\hline \multicolumn{5}{|l|}{ F Test } \\
\hline Inoculation (I) & $1.65^{\mathrm{ns}}$ & $0.08^{\mathrm{ns}}$ & $7.30^{*}$ & $3.68^{*}$ \\
\hline Nitrogen Dose (N) & $0.62^{\mathrm{ns}}$ & $1.78^{\mathrm{ns}}$ & $7.54^{*}$ & $0.02 *$ \\
\hline $\mathrm{I} \times \mathrm{N}$ & $0.34^{\mathrm{ns}}$ & $0.00^{\mathrm{ns}}$ & $0.11^{\mathrm{ns}}$ & $0.88^{\mathrm{ns}}$ \\
\hline CV (\%) & 19.04 & 21.19 & 15.72 & 21.69 \\
\hline \multicolumn{5}{|c|}{$2015 / 2016$} \\
\hline No Inoculation & $3037 \mathrm{~b}$ & 3331 & 4059 & 10427 \\
\hline Inoculation & $3528 \mathrm{a}$ & 3341 & 4192 & 11060 \\
\hline MSD (5\%) & 409 & 580 & 428 & 804 \\
\hline \multicolumn{5}{|l|}{ Nitrogen Dose } \\
\hline $0 \mathrm{~kg} \mathrm{ha}^{-1}$ & $2282 \mathrm{~b}$ & 2998 & $3861 \mathrm{~b}$ & $9142 \mathrm{c}$ \\
\hline $25 \mathrm{~kg} \mathrm{ha}^{-1}$ & $3497 \mathrm{a}$ & 3316 & $3964 \mathrm{ab}$ & $10778 \mathrm{~b}$ \\
\hline $50 \mathrm{~kg} \mathrm{ha}^{-1}$ & 4069 a & 3693 & $4550 \mathrm{a}$ & $12312 \mathrm{a}$ \\
\hline $\operatorname{MSD}(5 \%)$ & 608 & 864 & 637 & 1196 \\
\hline \multicolumn{5}{|l|}{ Teste $\mathrm{F}$} \\
\hline Inoculation (I) & $6.36^{*}$ & $0.00^{\mathrm{ns}}$ & $0.43^{\mathrm{ns}}$ & $2.73^{\mathrm{ns}}$ \\
\hline Nitrogen Dose $(\mathrm{N})$ & $29.35^{*}$ & $2.11^{\mathrm{ns}}$ & $4.43^{*}$ & $22.87^{*}$ \\
\hline $\mathrm{I} \times \mathrm{N}$ & $0.644^{\mathrm{ns}}$ & $0.21^{\mathrm{ns}}$ & $2.86^{\mathrm{ns}}$ & $1.90^{\mathrm{ns}}$ \\
\hline CV (\%) & 14.50 & 20.28 & 12.10 & 8.72 \\
\hline
\end{tabular}

MSD: minimal significant difference. Means followed by the same letter do not differ statistically from each other by the Tukey's test at $P \leq 0.05$. *, significant at $P \leq 0.05$; ${ }^{\text {ns }}$ not significant. 
Table 5

Effects of nitrogen doses on nutrient concentrations in the shoot dry mass of Urochloa brizantha cv. 'Marandu' during tree cuttings, in the seasons 2014/2015 and 2015/2016

\begin{tabular}{|c|c|c|c|c|}
\hline \multirow{3}{*}{ Nutrients } & \multirow{3}{*}{ Cuttings } & \multicolumn{3}{|c|}{ Nitrogen doses $\left(\mathrm{kg} \mathrm{ha}^{-1}\right)$} \\
\hline & & 0 & 25 & 50 \\
\hline & & \multicolumn{3}{|c|}{$2014 / 2015$} \\
\hline $\mathrm{P}\left(\mathrm{g} \mathrm{kg}^{-1}\right)$ & $3^{\text {rd }}$ & $2.16 \mathrm{~A}$ & $2.07 \mathrm{~A}$ & $1.70 \mathrm{~B}$ \\
\hline $\operatorname{Mg}\left(\mathrm{g} \mathrm{kg}^{-1}\right)$ & $1^{\text {st }}$ & $3.61 \mathrm{~B}$ & $4.73 \mathrm{~A}$ & $4.38 \mathrm{~A}$ \\
\hline $\mathrm{Fe}\left(\mathrm{mg} \mathrm{kg}^{-1}\right)$ & $1^{\mathrm{st}}$ & $61.00 \mathrm{~B}$ & $58.75 \mathrm{~B}$ & $83.25 \mathrm{~A}$ \\
\hline $\mathrm{Fe}\left(\mathrm{mg} \mathrm{kg}^{-1}\right)$ & $3^{\text {rd }}$ & $132.75 \mathrm{~A}$ & $116.63 \mathrm{AB}$ & $98.88 \mathrm{~B}$ \\
\hline $\operatorname{Mn}\left(\mathrm{mg} \mathrm{kg}^{-1}\right)$ & $1^{\mathrm{st}}$ & $84.75 \mathrm{AB}$ & 77.63 B & $102.88 \mathrm{~A}$ \\
\hline \multirow[t]{2}{*}{$\mathrm{Zn}\left(\mathrm{mg} \mathrm{kg}^{-1}\right)$} & $1^{\mathrm{st}}$ & $28.87 \mathrm{~B}$ & $34.38 \mathrm{AB}$ & $39.25 \mathrm{~A}$ \\
\hline & & \multicolumn{3}{|c|}{$2015 / 2016$} \\
\hline $\mathrm{N}\left(\mathrm{g} \mathrm{kg}^{-1}\right)$ & $1^{\text {st }}$ & $15.21 \mathrm{~B}$ & $16.34 \mathrm{AB}$ & $18.10 \mathrm{~A}$ \\
\hline $\mathrm{N}\left(\mathrm{g} \mathrm{kg}^{-1}\right)$ & $3^{\text {rd }}$ & $19.48 \mathrm{~B}$ & $20.98 \mathrm{~B}$ & $24.69 \mathrm{~A}$ \\
\hline $\mathrm{P}\left(\mathrm{g} \mathrm{kg}^{-1}\right)$ & $3^{\text {rd }}$ & $2.68 \mathrm{~A}$ & $2.36 \mathrm{AB}$ & $2.04 \mathrm{~B}$ \\
\hline $\mathrm{Cu}\left(\mathrm{mg} \mathrm{kg}^{-1}\right)$ & $3^{\text {rd }}$ & $6.12 \mathrm{~B}$ & $7.25 \mathrm{~A}$ & $7.75 \mathrm{~A}$ \\
\hline
\end{tabular}

Means followed by the same letter do not differ statistically from each other by the Tukey's test at $P \leq 0.05$. Only significant effects are shown.

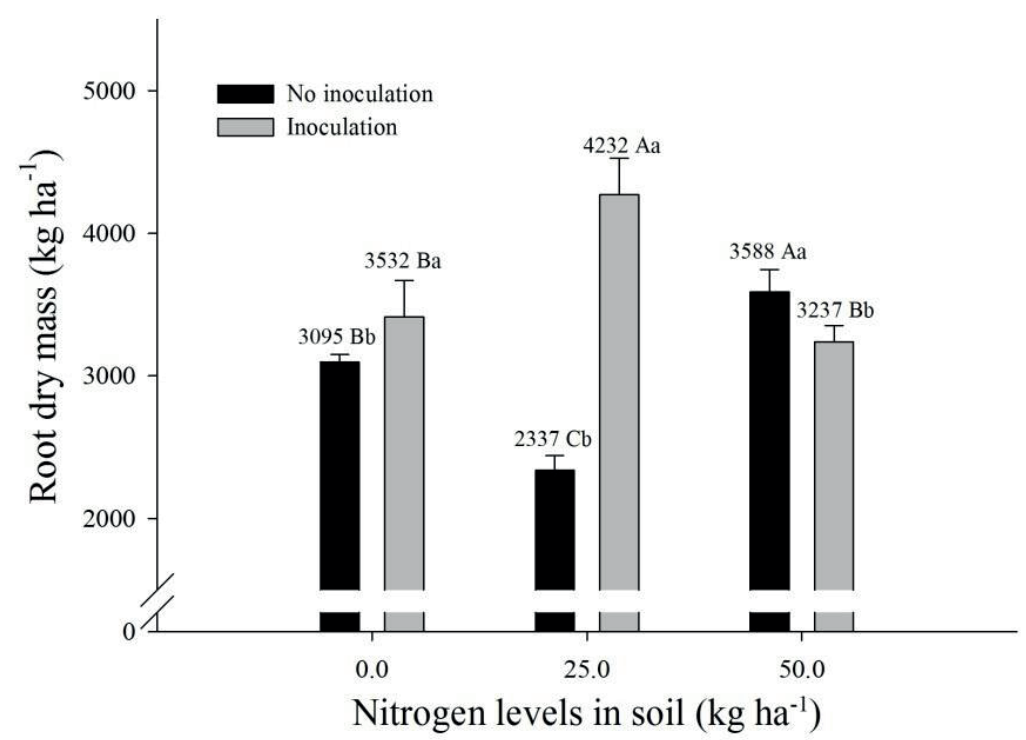

Figure 2. Effect of interaction between doses of $\mathrm{N}$ and inoculation with Azospirillum b. for the production of dry mass of roots of Urochloa brizantha cv. 'Marandu' at the end of the seasons 2014/2015. With respect to the Tukey test results, uppercase letters compare the doses of $\mathrm{N}$ under inoculation and non-inoculation conditions, while lowercase letters compare the same doses of $\mathrm{N}$ between inoculation and non-inoculation conditions. Vertical bars represent the standard deviation. 


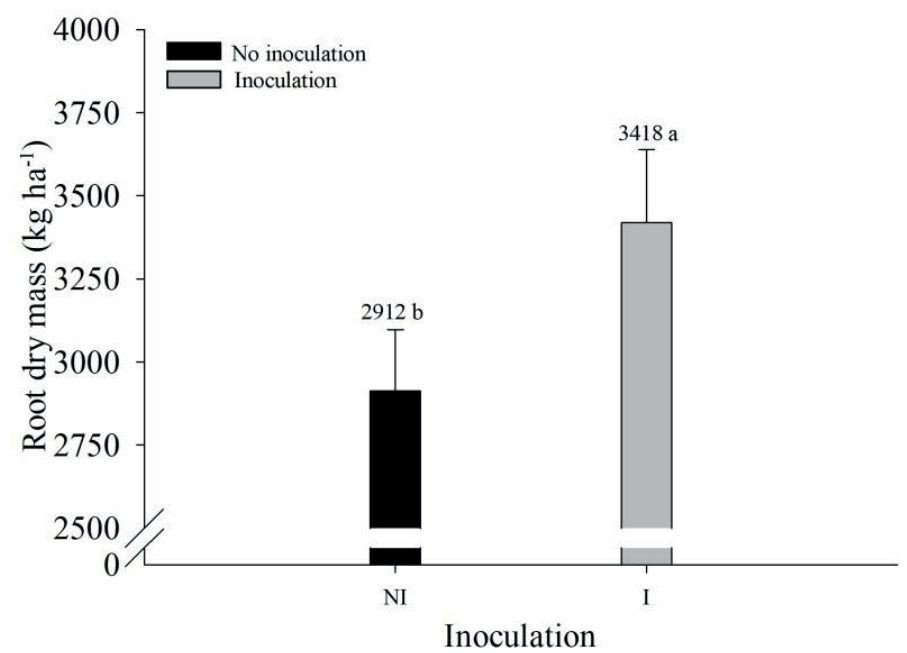

Figure 3. Isolated effect for inoculation with Azospirillum b. for the production of dry mass of roots of Urochloa brizantha cv. 'Marandu' at the end of the seasons 2015/2016. With respect to the Tukey test results, lowercase letters compare the conditions of inoculation and non-inoculation, regardless of doses of $\mathrm{N}$.

\section{Discussion}

The climatic conditions and soil after fertilization were in the ideal range for the 'Marandu' palisade grass production and development (Pedreira et al., 2017), but the inoculation with Azospirillum brasiliense strains Ab-V5 and Ab-V6 did not result in increased tiller numbers (Table 1). However, several studies have reported that complex plantmicrobe-environment interactions cause variations in the level of agronomic response to A. brasilense inoculation (Cassán \& Diaz-Zorita, 2016; Di Salvo, Ferrando, Fernández-Scavino, \& Salamone, 2018), including plant and bacterial genotypes (De Salamone et al., 2012).

Tiller response to $\mathrm{N}$ fertilization was only verified in the first cut in both years, while shoot dry mass increased only in the first cut of the second year. The number of tillers was within the range of $430 \mathrm{~m}^{-2}$ in the treatment without mineral $\mathrm{N}$ in the first cutting, and $965 \mathrm{~m}^{-2}$ in the treatment with Azospirillum in the third cutting, both in the second year. Similar results have been verified in studies testing $\mathrm{N}$ fertilization in 'Marandu' palisade grass during the summer (Pedreira et al., 2017; Silva, Costa, Faquin, Oliveira, \& Bernardes, 2013). The lack of tiller number response to $\mathrm{N}$ fertilization in the second and third cuttings, and accumulated cuttings as well, may be associated with sufficient $\mathrm{N}$ supply from the mineralization of soil organic matter. The soil tillage system based on plowing and harrowing before the pasture sowing stimulates the mineralization of SOM and nutrient supply, thus improving the plant nutrition, especially later on in the second and third cuts, because of more time elapsed for mineralization compared to the first cut (Zhu et al., 2014).

In addition, the number of tillers may not represent the shoot dry mass, since the tillers may have different sizes and weights in response to the inserted environment and may not being representative when expressed as number instead of total mass. An increase in the shoot dry mass of Brachiaria spp. in response to the increase in the number of tillers has been observed (Fagundes et al., 2006; Matthew, Assuero, Black, \& Hamilton, 2000). In the present research, however, the tiller formation was stimulated in some cases, but the increase did not correspond to a higher shoot dry mass yield, except in the first cuts of the two years, in which an increase in the tiller numbers in response to $\mathrm{N}$ fertilization resulted in increased 
shoot dry mass yield. Increase in the tiller numbers is especially induced in environments that are limited in $\mathrm{N}$, because this nutrient is involved in cell division processes, and it is directly associated with vegetative production (Fagundes et al., 2006; Marschner, 2011).

The lack of response of tillers to $\mathrm{N}$ in the following cuttings suggests that this nutrient was not limiting for plant development in that environment in the second and third cuttings. At those sampling times, because the tussocks were already established as well as the root system, some $\mathrm{N}$ in the remaining plant biomass could have been enough to allow the development of further tillers and constrain the response to the $\mathrm{N}$ applied as topdressing. The inoculation with Azospirillum also did not cause any change in the tiller numbers. However, other studies have shown the positive effects of PGPR on grasses, especially shoot and root dry mass, by means of several mechanisms (Araújo, Guaberto, \& Silva, 2012; Shaharoona et al., 2007).

The plant response to inoculation with plant growth promotion depends on the interaction with the environment, and sometimes an expected response may not occur. Over the two years, the Azospirillum inoculation in seeds of 'Marandu' palisade grass significantly increased the dry mass production in two out of six cuttings, and in the first year, the effect was observed in the accumulated cuttings. These results are promising for the use of inoculation with PGPR during pasture installation. Martínez, Crowley, Mora and Jorquera (2015) also observed an increase by $29 \%$ in the dry mass production with the Azospirillum inoculation in grasses, especially oats (Avena sativa).

The overall increase in shoot dry mass due to inoculation was $13 \%$ and $6 \%$ in the first and second years, respectively, compared with the control. Positive results of inoculation are associated with several plant-growth-promoting mechanisms, including biological nitrogen fixation and changes in root morphology and architecture resulting from the phytohormone production, which directly increases the lateral root branching and the incidence and length of root hairs (El Zemrany et al., 2007; Kazi et al., 2016). Because of the changes in root morphological traits, the absorptive surface increases and the nutrients applied to the system, including $\mathrm{N}$, are more effectively acquired, and there is a more effective water uptake from soil (Steenhoudt \& Vanderleyden, 2000). As a general improvement of the performance of Azospirilluminoculated plants, this can be an effective strategy to increase the survival of forages like Brachiaria, minimizing stresses imposed by water restrictions and animal defoliation (Pedreira et al., 2017).

Hungria et al. (2016) found positive effects from Azospirillum inoculated in seeds on the development of two genotypes of Brachiaria spp. in different geographic regions of Brazil. The $\mathrm{N}$ fertilization alone and in association with inoculation by Azospirillum promoted increases in the shoot dry mass between $5.4 \%$ and $22.1 \%$, in addition to a general increase by $10 \%$ in the concentration of proteins. This means that the inoculation with Azospirillum increased the forage not only quantitatively, but also qualitatively, resulting in a total increase of proteins per area by $25 \%$. Other authors have also observed increases in shoot dry mass yield in plants inoculated plantgrowth-promoting bacteria (De Salamone et al., 2010; Díaz-Zorita \& Fernández-Canigia, 2009; Kazi et al., 2016), demonstrating its general, nonspecific potential as plant-growth-promoter.

However, converse results obtained by Hanisch, Balbinot and Vogt (2017) showed no effects of Azospirillum brasilense inoculation on 'Marandu' seeds associated to $\mathrm{N}$ doses on shoot dry mass over two years of evaluation. Divergent results with the use of plant-growth-promoting bacteria can be explained by factors influencing the host plant and the bacterial survival and activity in the rhizosphere, such as soil chemical properties and especially rainfall, which differentially affect the efficiency of 
the bacteria as well as the fertilization with mineral N (Kazi et al., 2016).

Regarding the nutrient concentrations, leaf $\mathrm{N}$ increased with fertilizer application in the second year in the first and in the third cuttings, while $\mathrm{P}$ concentration decreased with $\mathrm{N}$ application in the third cut in both years (Table 5). Magnesium and $\mathrm{Cu}$ increased with the $\mathrm{N}$ doses. On the other hand, Fe had contrasting behavior in the first year, depending on the cutting. Nutrient decreases with increase of $\mathrm{N}$ can be associated with the dilution effect of higher dry mass production (Marschner, 2011). However, increases in the other nutrient concentrations might be related to the improvement of plant effectiveness in nutrient uptake, since there is a physical response to the increase of the root absorptive surface, including an increase of specific uptake mechanisms via transporters, which are mainly proteins depending on $\mathrm{N}$ to be formed. The concentrations of all nutrients were within the range considered adequate for this forage species (Reuter \& Robinson, 1997).

The root dry mass production showed a distinct behavior over the two years. In the first year, the fertilization of $25 \mathrm{~kg} \mathrm{~N}^{-1}$ plus the inoculation resulted in higher root production, about 36\% higher than the average of the other treatments. In the second year, the inoculation of Azospirillum increased the development of the root system by $17 \%$. A lower RDM production was observed when applying $50 \mathrm{~N} \mathrm{~kg} \mathrm{ha}^{-1}$ mineral fertilizer plus inoculation with Azospirillum, indicating that higher $\mathrm{N}$ dosages have a detrimental effect on the activity of these microorganisms (Figure 2).

These results confirm previous reports on the increases in roots in response to inoculation with Azospirillum because of hormonal mechanisms stimulating root growth, especially IAA-related compounds (Cassán \& Diaz-Zorita, 2016; El Zemrany et al., 2007; Kazi et al., 2016; Piccinin et al., 2013). In the second year, however, no effect of inoculation was observed on roots, confirming that the action of the bacteria is subject to variation depending on the soil and climatic conditions (Pedreira et al., 2017). Again, the Azospirillum effects on roots seem to be highlighted when the plants are subjected to some environmental limitation, within certain limits, like drought at the beginning of the plant establishment. In this case, the increase of roots is not only related to the increase of plant capacity to uptake water and nutrients, but it is also an important way of $\mathrm{C}$ immobilization in the soil (Hungria et al., 2016). In April 2015, evapotranspiration was higher than precipitation (Figure 1), and this may have contributed to higher root production with the presence of Azospirillum (Figure 2), acting as a plant physiological defense mechanism due to stress conditions (Cassán \& Diaz-Zorita, 2016; Kazi et al., 2016), especially in the inoculation and application of $25 \mathrm{~kg} \mathrm{~N} \mathrm{ha}^{-1}$.

Considering the potential for increasing biomass production by 'Marandu' palisade grass, Azospirillum is a promising treatment to increase the effectiveness of mineral fertilizers during the pasture formation, notably $\mathrm{N}$ fertilizers. For example, Azospirillum inoculation associated with $40 \mathrm{~kg} \mathrm{ha}^{-1}$ of $\mathrm{N}$ as topdressing 30 days after sowing corresponded to an extra application of $40 \mathrm{~kg} \mathrm{ha}^{-1}$ of mineral N (Hungria et al., 2013). This is an important issue to be considered for the reduction of the environmental impacts of mineral $\mathrm{N}$ fertilizers because of more efficient use. Besides being converted into proteins in plant biomass, the more efficient use of mineral $\mathrm{N}$ by plants inoculated with Azospirillum reduces nitrate losses to groundwater by leaching or greenhouse gas emissions to the atmosphere via denitrification. Thus, the use of more environmentally-friendly tools for pasture establishment is important for maintaining the sustainability of livestock activities, as it improves the land efficiency and nutrient use, helps soil and water conservation and contributes for the sequestration of $\mathrm{C}$ in either plant shoot biomass (Hungria et al., 2016) or in the soil as roots. 


\section{Conclusion}

Seed inoculation of Urochloa brizantha cv. 'Marandu' with Azospirillum brasilense increased root and shoot dry mass production in some cuts, without influencing tiller numbers. Nitrogen fertilization altered $\mathrm{N}, \mathrm{Mg}, \mathrm{P}, \mathrm{Fe}, \mathrm{Mn}, \mathrm{Zn}$, and $\mathrm{Cu}$ concentrations in shoot dry mass.

\section{Conflict of interest}

The authors have no conflicts of interest to declare.

\section{References}

Araújo, F. F., Guaberto, L. M., \& Silva, I. F. (2012). Bioprospection of plant growth promoter rhizobacteria in Brachiaria brizantha. Brazilian Journal of Animal Science, 41(3), 521-527. doi: 10.1590/S1516-35982012000300007

Baldani, I. J., Reis, V. M., Videira, S. S., Boddey, L. H., \& Baldani, V. L. B. (2014). The art of isolating nitrogen-fixing bacteria from non-leguminous plants using $\mathrm{N}$-free semi-solid media: a practical guide for microbiologists. Plant and Soil, 384(1-2), 413-431. doi: 10.1007/s11104-014-2186-6

Bashan, Y., \& de-Bashan, L. E. (2005). Fresh-weight measurements of roots provide inaccurate estimates of the effects of plant growth-promoting bacteria on root growth: a critical examination. Soil Biology and Biochemistry, 37(10), 1795-1804. doi: 10.1016/j. soilbio.2005.02.013

Carvalhais, L. C., Dennis, P. G., Fan, B., Fedoseyenko, D., Kierul, K., Becker, A.,... Borriss, R. (2013). Linking plant nutritional status to plant-microbe interactions. PLoS One, 8(7), 1-13, e68555. doi: 10.1371/journal.pone.0068555

Cassán, F., \& Diaz-Zorita, M. (2016). Azospirillum sp. in current agriculture: from the laboratory to the field. Soil Biology and Biochemistry, 103(12), 117-130. doi: 10.1016/j.soilbio.2016.08.020

Cezário, A. S., Ribeiro, K. G., Santos, S. A., Valadares, S. de C., Fo., \& Pereira, O. G. (2015). Silages of Brachiaria brizantha cv. Marandu harvested at two regrowth ages: microbial inoculant responses in silage fermentation, ruminant digestion and beef cattle performance. Animal Feed Science and Technology, 208(10), 33-43. doi: 10.1016/j. anifeedsci.2015.06.025

Chinnadurai, C., Gopalaswamy, G., \& Balachandar, D. (2014). Long term effects of nutrient management regimes on abundance of bacterial genes and soil biochemical processes for fertility sustainability in a semi-arid tropical Alfisol. Geoderma, 232(11), 563572. doi: 10.1016/j.geoderma.2014.06.015

De Salamone, I. E. G., Di Salvo, L. P., Ortega, J. S. E., Sorte, P. M. B., Urquiaga, S., \& Teixeira, K. R. (2010). Field response of rice paddy crop to Azospirillum inoculation: physiology of rhizosphere bacterial communities and the genetic diversity of endophytic bacteria in different parts of the plants. Plant and Soil, 336(1-2), 351-362. doi: 10.1007/ s11104-010-0487-y

De Salamone, I. E. G., Funes, J. M., Di Salvo, L. P., Escobar-Ortega, J. S., D'Auria, F., Ferrando, L., \& Fernandez-Scavino, A. (2012). Inoculation of paddy rice with Azospirillum brasilense and Pseudomonas fluorescens: impact of plant genotypes on rhizosphere microbial communities and field crop production. Applied Soil Ecology, 61(10), 196-204. doi: 10.1016/j.apsoil.2011.12.012

Delaporte-Quintana, P., Grillo-Puertas, M., Lovaisa, N. C., Teixeira, K. R., Rapisarda, V. A., \& Pedraza, R. O. (2017). Contribution of Gluconacetobacter diazotrophicus to phosphorus nutrition in strawberry plants. Plant and Soil, 419(1-2), 335-347. doi: $10.1007 / \mathrm{s} 11104-017-3349-\mathrm{z}$

Di Salvo, L. P., Ferrando, L., Fernández-Scavino, A., \& Salamone, I. E. G. de. (2018). Microorganisms reveal what plants do not: wheat growth and rhizosphere microbial communities after Azospirillum brasilense inoculation and nitrogen fertilization under field conditions. Plant and Soil, 424(1-2), 405-417. doi: 10.1007/s11104-017-3548-7

Dias, M. B., Fo. (2014). Diagnóstico das pastagens no Brasil. Belém: EMBRAPA Amazônia Oriental.

Díaz-Zorita, M., \& Fernández-Canigia, M. V.(2009). Field performance of a liquid formulation of Azospirillum brasilense on dryland wheat productivity. European Journal of Soil Biology, 45(1), 3-11. doi: 10.1016/j. ejsobi.2008.07.001

El Zemrany, H., Czarnes, S., Hallett, P. D., Alamercery, S., Bally, R., \& Monrozier, L. J. (2007). Early changes in root characteristics of maize (Zea mays) following seed inoculation with the PGPR Azospirillum lipoferum CRT1. Plant and Soil, 291(1-2), 109-118. doi: 10.1007/s11104-006-9178-0 
Fagundes, J. L., Fonseca, D. D., Morais, R. D., Mistura, C., Vitor, C. M. T., Gomide, J. A.,... \& Lambertucci, D. M. (2006). Avaliação das características estruturais do capim-braquiária em pastagens adubadas com nitrogênio nas quatro estações do ano. Revista Brasileira de Zootecnia, 35(1), 30-37.

Hanisch, A. L., Balbinot, J., \& Vogt, G. A. (2017). Productive performance of Urochloa brizantha cv. Marandu as a function of inoculation with Azospirillum and nitrogen doses.Agro@mbienteOnline, 11(3), 200-208.

Huang, X. F., Zhou, D., Lapsansky, E. R., Reardon, K. F., Guo, J., Andales, M. J.,... \& Manter, D. K. (2017). Mitsuaria sp. and Burkholderia sp. from Arabidopsis rhizosphere enhance drought tolerance in Arabidopsis thaliana and maize (Zea mays L.). Plant and Soil, 419(1-2), 523-539. doi: 10.1007/ s11104-017-3360-4

Hungria, M., Campo, R. J., Souza, E. M., \& Pedrosa, F. O. (2010). Inoculation with selected strains of Azospirillum brasilense and A. lipoferum improves yields of maize and wheat in Brazil. Plant and Soil, 331(1-2), 413-425. doi: 10.1007/s11104-009-0262-0

Hungria, M., Nogueira, M. A., \& Araujo, R. S. (2013). Co-inoculation of soybeans and common beans with rhizobia and azospirilla: strategies to improve sustainability. Biology and Fertility of Soils, 49(7), 791-801. doi: 10.1007/s00374-012-0771-5

Hungria, M., Nogueira, M. A., \& Araujo, R. S. (2016). Inoculation of Brachiaria spp. with the plant growthpromoting bacterium Azospirillum brasilense: an environment-friendly component in the reclamation of degraded pastures in the tropics. Agriculture, Ecosystems \& Environment, 221(7), 125-131. doi: 10.1016/j.agee.2016.01.024

Kazi, N., Deaker, R., Wilson, N., Muhammad, K., \& Trethowan, R. (2016). The response of wheat genotypes to inoculation with Azospirillum brasilense in the field. Field Crops Research, 196(12), 368-378. doi: 10.1016/j.fcr.2016.07.012

Lopes, A. S., \& Guilherme, L. G. (2016). A career perspective on soil management in the Cerrado Region of Brazil. Advances in Agronomy, 137, 1-72. doi: 10.1016/bs.agron.2015.12.004

Malavolta, E., G. C. Vitti, \& Oliveira S. A. de. (1997). Evaluation of plant nutrient status: principles and their application. (2a. ed.). Piracicaba: Potafos.

Marschner, H. (2011). Marschner's mineral nutrition of higher plants. London: Academic Press.
Martínez, O. A., Crowley, D. E., Mora, M. L., \& Jorquera, M. A. (2015). Short-term study shows that phytatemineralizing rhizobacteria inoculation affects the biomass, phosphorus (P) uptake and rhizosphere properties of cereal plants. Journal of Soil Science and Plant Nutrition, 15(1), 153-166. doi: 10.4067/ S0718-95162015005000013

Matthew, C., Assuero, S. G., Black, C. K., \& Hamilton, N. R. S. (2000). Tiller dynamics of grazed swards. In G. Lemaire, J. Hodgson, \& A. Moraes (Eds.), Grassland Ecophysiology and Grazing Ecology (Cap. 7, pp. 127-150). Wallingford: CABI.

Medica, J. A. D. S., Reis, N. S., \& Santos, M. E. R. (2017). Morfologic characterization on Marandu grass pastures submitted to defoliation frequencies and fertilization levels. Ciência Animal Brasileira, 18(1), 1-13, e40460. doi: 10.1590/1089-6891v18e40460

Morais, J. A. S., Queiroz, M. F. S., Keli, A., Vega, A., Fiorentini, G., Canesin, R. C.,... \& Berchielli, T. T. (2014). Effect of supplementation frequency on intake, behavior and performance in beef steers grazing Marandu grass. Animal Feed Science and Technology, 189(3), 63-71. doi: 10.1016/j. anifeedsci.2014.01.005

Moutia, J. F. Y., Saumtally, S., Spaepen, S., \& Vanderleyden, J. (2010). Plant growth promotion by Azospirillum sp. in sugarcane is influenced by genotype and drought stress. Plant and Soil, 337(12), 233-242. doi: 10.1007/s11104-010-0519-7

Nesper, M., Bünemann, E. K., Fonte, S. J., Rao, I. M., Velásquez, J. E., Ramirez, B.,... \& Oberson, A. (2015). Pasture degradation decreases organic P content of tropical soils due to soil structural decline. Geoderma, 257(11), 123-133. doi: 10.1016/j. geoderma.2014.10.010

Pedreira, B. C., Barbosa, P. L., Pereira, L. E. T., Mombach, M. A., Domiciano, L. F., Pereira, D. H., \& Ferreira, A. (2017). Tiller density and tillering on Brachiaria brizantha cv. Marandu pastures inoculated with Azospirillum brasilense. Arquivo Brasileiro de Medicina Veterinária e Zootecnia, 69(4), 1039-1046. doi: 10.1590/1678-4162-9034

Pedreira, B. C., Pedreira, C. G. S., \& Silva, S. C. D. (2007). Sward structure and herbage accumulation in Brachiaria brizantha cultivar Xaraés in response to strategies of grazing. Pesquisa Agropecuária Brasileira, 42(2), 281-287. doi: 10.1590/S0100204X2007000200018 
Piccinin, G. G., Braccini, A. L., Dan, L. G., Scapim, C. A., Ricci, T. T., \& Bazo, G. L. (2013). Efficiency of seed inoculation with Azospirillum brasilense on agronomic characteristics and yield of wheat. Industrial Crops and Products, 43(3), 393-397. doi: 10.1016/j.indcrop.2012.07.052

Pimentel-Gomes, F., \& Garcia, C. H. (2002). Estatística aplicada a experimentos agronômicos e florestais: exposição com exemplos e orientações para uso de aplicativos. Piracicaba: FEALQ.

Quaggio, J. A., Van Raij, B., \& Malavolta, E. (1985). Alternative use of the SMP-buffer solution to determine lime requirement of soils. Communications in Soil Science and Plant Analysis, 16(3), 245-260. doi: $10.1080 / 00103628509367600$

Reuter, D., \& Robinson, J. B. (1997). Plant analysis: an interpretation manual. Collingwood: CSIRO Publishing.

Santos, H. G. dos, Jacomine, P. K. T., Anjos, L. H. C. dos, Oliveira, V. A. de, Lumbreras, J. F., Coelho, M. R.,... \& Cunha, T. J. F. (2018). Sistema brasileiro de classificação de solos. EMBRAPA Solos-Livro Técnico (INFOTECA-E).
Shaharoona, B., Jamro, G. M., Zahir, Z. A., Arshad, M., \& Memon, K. S. (2007). Effectiveness of various Pseudomonas spp. and Burkholderia caryophylli containing ACC-Deaminase for improving growth and yield of wheat (Triticum aestivum I.). Journal of Microbiology and Biotechnology, 17(8), 1300-1307.

Silva, D. R. G., Costa, K. A. de P., Faquin, V., Oliveira, I. P. de, \& Bernardes, T. F. (2013). Doses e fontes de nitrogênio na recuperação das características estruturais e produtivas do capim-marandu. Revista Ciência Agronômica, 44(1), 184-191.

Steenhoudt, O., \& Vanderleyden, J. (2000). Azospirillum, a free-living nitrogen-fixing bacterium closely associated with grasses: genetic, biochemical and ecological aspects. FEMS Microbiology Reviews, 24(4), 487-506. doi: 10.1111/j.1574-6976.2000. tb00552.x

Taiz, L., Zeiger, E., Møller, I. M., \& Murphy, A. (2017). Fisiologia e desenvolvimento vegetal. Porto Alegre: Artmed Editora.

Zhu, B., Gutknecht, J. L., Herman, D. J., Keck, D. C., Firestone, M. K., \& Cheng, W. (2014). Rhizosphere priming effects on soil carbon and nitrogen mineralization. Soil Biology and Biochemistry, 76(6), 183-192. doi: 10.1016/j.soilbio.2014.04.033 